\title{
Organic Treatment effects on Ferritic soil quality and Tomato (Lycopersicon esculentum Mill.) Yield
}

\author{
Ghislaine Ndonkeu Mangoumou ${ }^{1 *}$, Julienne Nguefack ${ }^{1}$, Joseph Blaise \\ Dongmo Lekagne ${ }^{1}$, Charles Dakole Daboy ${ }^{1}$, Jean Claude Nguepsi ${ }^{1}$ and Paul \\ Moundipa Fewou ${ }^{1}$
}

\author{
Department of Biochemistry, Faculty of Sciences, University of Yaoundé I, PO Box 812Yaounde, Cameroon \\ *Corresponding Author
}

\begin{abstract}
The impact of the combination of plant (Tithonia diversifolia) (Td) plus cow dung (Cd) as biofertilizer and aqueous extract of Callistemon citrinus (CAL) leaves as biofungicide on physicochemical properties, and the microbial biomass in carbon $(M B C)$ and nitrogen (MBN) of soil and on tomato yield were assessed under field condition. The experimental design was a complete block design with 2 factors (soil amendment and plant sprays) and 3 repetitions. The soil treatment included organic amendment $(O A): T d+$ Cd at the ratio of 3:4 (w/w)/plant; inorganic amendment (IA): 21:8:8 NPK (26.2 g/plant) and potassium sulfate (4g/plant); and control (unamended soil). The field treatments were plants sprayed with: $5 \%(w / v) C A L ; 5 \%$ $(w / v)$ Mancozeb (M); and water (W). All amendments except IA did not significantly modify the soil organic matter $\left(<2.4 \mathrm{mg} \mathrm{kg}^{-1}\right)$ and organic carbon content. An increase of $23.15 \%$ and $30.60 \%$ of calcium concentration and cation exchangeable capacity (CEC) respectively, was recorded in $O A$ soil compared to the soil before cultivation $(S B C)(P<0.05)$. Copper and zinc contents in $O A$ soil were reduced respectively by $49 \%$ and $48.5 \%$ compared to SBC. The highest concentration of $M B C$ was recorded in OA.M plot. The different combine treatments (OA.CAL, IA.M, and OA.M) increased tomato yield by 3.4; 3; and 5.3 fold, respectively compared to their controls. This study provided new information about the organic amendment on soil and plant sprayed with $C$. citrinus extract as a green alternative to conventional input that might improve soil quality and crop yield.
\end{abstract}

Keywords - microbial biomass, organic inputs, soil physicochemical properties, tomato.

\section{INTRODUCTION}

Tomato (Lycopersicon esculentum Mill.) is among the most important fruit vegetables in the world due to the high potential health-promoting properties and their contents in flavonoids, carotenoids, and vitamins (Aghofack-Nguemezi and Schawb, 2014). Tomato yield and production were 188t/ha, 182301395tons and 12.1t/ha, 1279853 tons respectively in the world and Cameroon (FAOSTAT, 2019). Pests and diseases are among the most important constraints of tomato culture in Cameroon. The farmers currently apply conventional agrochemicals in an abusive and inappropriate manner (Konje et al. 2019). The use of pesticides and their residues poses a real public health problem to farmers, consumers and the environment (Zinkakuba et al. 2019). It is therefore urgent to search for alternative methods that are environmentally friendly and with fewer health risks to the consumers.

The disease control of crops through the use of plant-based biopesticides and antagonistic microorganisms has become an interesting alternative (Olanya and Larkin, 2006). In Cameroon, local plant extracts have been reported as having inhibitory properties in vitro and in vivo against various pathogens (Goufo et al. 2010; Ndonkeu et al. 2013; Mekam et al. 2019). Botanicals with antifungal compounds have been identified and can be exploited for the management of plant diseases because they have low mammalian toxicity, target specificity, biodegradability and contain many active ingredients (Kagale et al. 2004). Callistemon citrinus because of its antifungal activity notably against Phytophtora infestans of tomato (Galani et al. 2013; Dakole 
et al. 2016), on Alternaria padwickii and Bipolaris oryzae of rice (Nguefack et al. 2013) is used as a biocontrol agent.

To achieve high tomato yield, farmers used chemical fertilizers, which could be responsible for soil acidification and the decrease in the microbiological activity of soils (Monkiedje et al. 2006). Also, the use of agrochemicals causes the long-term accumulation of heavy metals in water and soil. These heavy metals are assimilated by plants and enter the food chain causing animal and human health problems (Zwolak et al. 2019). As well, the rising costs of inorganic fertilizers made them too expensive.

Tithonia diversifolia (Asteracea) green biomass is an effective source of nutrients and has been used successfully to improve soil fertility and crop yields in Kenya (Jama et al. 2000). Aguyoh et al. (2010) reported a significant and positively correlated increase in a total yield of watermelon with increasing application rates of $T$. diversifolia manure. In that study, $T$. diversifolia application enhanced the total yield of watermelon by between $8.5 \%$ and $31 \%$ compared to the control. $T$. diversifolia can improve the physical and chemical properties of soil and increase nutrients in the soil (Crespo et al. 2011) and maintain soil fertility for a long period (Babajide et al. 2008).

Cattle manure used for its added value for soil carbon sequestration, and it's capacity for storing and releasing nutrients over a longer period (Diacono and Montemurro, 2010). In Uganda, although a significant number of farmers have adopted the use of cattle manure on their farms, they normally use it untreated and directly from animal barns (Komakech et al. 2014). According to Adegunloye et al. (2007), the $\mathrm{C}$ : $\mathrm{N}$ ratio in cow dung manure is an indication that it could be a good source of protein for the microbes involved in the decomposition of organic matter.

Each amendment applied to the soil may not contain all required nutrients in a high amount at the same time. Therefore, to have a balanced nutrient supply, the addition of more than one amendment to the soil may be required. Adekiya (2018). Consequently, in this work, it was planned to test a biofertilizer made of a mixture of $\mathrm{Td}+\mathrm{Cd}$. The present study aimed to evaluate the impact of the combination of plant (Tithonia diversifolia) (Td) plus cow dung (Cd) as biofertilizer and aqueous extract of Callistemon citrinus (CAL) leaves as biofungicide on physicochemical properties and the microbial biomass in carbon $(\mathrm{MBC})$ and nitrogen $(\mathrm{MBN})$ of soil and on tomato yield in field condition.

\section{MATERIAL AND METHODS}

1.1 Experimental site
The experiment was conducted at Nkolbisson-Yaounde (Eloundem) Centre Region of Cameroon from December to May 2018. The study site is located at an altitude of $711 \mathrm{~m}$ above sea level and situated at latitude $3^{\circ} 51^{\prime} 14 " \mathrm{~N}$ and longitude $11^{\circ} 44^{\prime} 26^{\prime \prime E}$. The annual rainfall distribution is bimodal (lighter rains between March and June and a more intense rainy season between September and November) with peak rainfall in May and October. The area has a mean annual rainfall of approximately $1500-2000 \mathrm{~mm}$ and a mean annual temperature of $24.7^{\circ} \mathrm{C}$. The relative humidity range between 50 and $80 \%$ in the dry season and 70 and $90 \%$ in the rainy season. The most dominant soil types at Nkolbisson is ferritic and acidic (pH 5-6).

\subsection{Field design}

The variety of tomato (Cobra) seeds used was produced by the French firm TECHNISEM. Tomato seeds were sown in nursery beds enriched with the mixture of Tithonia diversifolia $(T d)$ leaves and cow dung (Cd) powders at the dose of 312.5 and $250 \mathrm{~g} / \mathrm{m}^{2}$, respectively. The tomato plants used were 35 days old and had three to four true fully expending leaves.

The field experiment was laid out in a complete block design, with 9 plots per block and three repetitions. Each plot contained 16 plants and made up of 4 rows. Tomato seedling transplanting was done at an interval of $0.5 \mathrm{~m}$ between rows and $0.5 \mathrm{~m}$ between plants of the row. In each plot, 16 pockets were dug and each filled with organic amendment (Tithonia diversifolia leaves (75g/plant) and cow dung (100g/plant) powders) one week before transplanting. In the inorganic plots, 21:8:8 N/P/K (26.2 g/plant) was applied one week after transplanting and potassium sulfate $\left(50 \% \mathrm{~K}_{2} \mathrm{O}\right.$ and $\left.45 \% \mathrm{SO}_{3}\right)(4 \mathrm{~g} /$ plant $)$ at fruit set stage. Organic and inorganic nitrogen was applied an equivalent of $5 \mathrm{~g}$ of $\mathrm{N} /$ plant. Plants were sprayed 10 times (twice/month) with water, $5 \%$ of both biopesticide, and chemical pesticide. The biopesticide was obtained by soaking the powder of dried leaves of Callistemon citrinus in water for 24 hours. The chemical fungicide was mancozeb.

\subsection{Soil sampling}

In each plot, the soil was sampled at a depth of $0-20 \mathrm{~cm}$ in three different areas diagonally. All sample soils were mixed to form a composite. $0.5 \mathrm{~kg}$ of the composite was air-dried, ground, and sieved $(<0.25 \mathrm{~mm})$. Then serve as a substrate for the physicochemical analysis. A part of the composite was sieved $(<0.5 \mathrm{~mm})$ and then stored at $4^{\circ} \mathrm{C}$ until microbial biomass analyses.

\subsection{Physicochemical analyses}

Soil properties were observed both before and at the end of the experiment. Granulometry was determined by the 
Robinson-Köhn pipette method. Soil $\mathrm{pH}$ was measured in $1: 2.5$ soil to solution ratio in distilled water $(\mathrm{pH}-\mathrm{H} 20)$. Organic carbon (OC) was estimated by oxidation with potassium dichromate and titration with ferrous sulfate (Walkley and Black, 1934). Total nitrogen was estimated by the Kjeldahl method. Iron, copper, lead, and zinc were determined colorimetrically after reduction with dithionatecitrate-bicarbonate (DCB). Available phosphorus was determined by the Bray II method (Bray and Kurtz, 1945). Calcium was estimated by a complexometric and titrimetric method with tetra acetic ethylene diamine acid of an ammonium acetate extract at $\mathrm{pH} 7$ of the sample. Cation exchange capacity (CEC) was determined by percolating $2.5 \mathrm{~g}$ of soil with $100 \mathrm{~mL}$ of $1 \mathrm{~N}$ ammonium acetate buffered at $\mathrm{pH} 7$, removing the excess with ethanol and displacing the absorb $\mathrm{NH}_{4}{ }^{+}$ions with $1 \mathrm{~N} \mathrm{KCl}$, determining the collected $\mathrm{NH}_{4}{ }^{+}$ions by distillation and titration with $0.01 \mathrm{~N}$ sulfuric acid.

\subsection{Study of soil microflora}

Microbial biomass was determined by fumigationextraction (Chaussod et al. 1988; Wu et al. 1990). Carbon determination was done by Walkley and Black (1934) and nitrogen determination by Kjeldahl. The coefficients used to determine the biomasses were: $\mathrm{KeC}=0.38$ and $\mathrm{KeN}=0.68$.

\subsection{Tomato yield}

From each plot, matured tomato fruits were harvested each week and total fruit weight was determined. Fruit product data were summed up of the total fruit weight from consecutive harvests and converted into tons per hectare to estimate the fruit yield.

\subsection{Statistical analysis of data}

The results were subjected to statistical analysis using IBM SPSS Statistics 22 software, particularly variance analysis (ANOVA) and significant differences were assessed using the Student Newman Keuls (SNK) test at the 5\% probability threshold. XLSTAT 2007 software was used for the Principal Component Analysis (PCA).

\section{RESULTS AND DISCUSSION}

3.1 Effects of organic amendment on soil physicochemical properties

The effect of different amendments on soil granulometry showed some variations in particle contents (Table1). The silt content was above $45 \%$, and double that of sand. Clay and sand contents from soil samples collected before cultivation (SBC) and control soil, were significantly $(\mathrm{P}<0.05)$ lower, compared to those of organic amended (OA) and inorganic amended (IA) soils. Based on the USDA textural diagram, the texture observed in SBC and control soil was silty clay loam and clay loam in OA and IA soils. Silt clay texture was favourable for tomato cultivation.

The carbon-nitrogen ratio $(\mathrm{C}: \mathrm{N})$ was found to be 8 in $\mathrm{OA}$ soil combined to plant treated with the aqueous extract of $C$. citrinus (OA.CAL). Also, C:N was less than 14 in SBC, IA soil, OA soil combined to plant treated with mancozeb (OA.M) and 16.75 on the control soil combined to plant treated with water (Control.W) (Table 2). IA.CAL soil (C:N $=8$ ) with the same soil organic matter (SOM) content as SBC soil $(\mathrm{C}: \mathrm{N}=11)$ had higher total nitrogen $(\mathrm{TN})$ concentration. Hubert and Schaub (2011) showed that high carbon-nitrogen $(\mathrm{C}: \mathrm{N} \geq 13.70)$ made decomposition slow to difficult and did not allow good mineralization of organic matter. Soils, where plants have been sprayed with water, had the lowest amounts of available phosphorus (P) $(\mathrm{P}<0.05)$. This could be explained by the fixation of available phosphorus in these soils by protons and cations such as $\mathrm{Ca}^{++}$and thus transforming it into a compound not assimilable by the plant (Rivaie et al. 2008). The highest $\mathrm{P}$ content (15.64mg.kg-1) of about 2 fold that of $\mathrm{SBC}(\mathrm{P}<0.05)$ was recorded in OA.CAL soil. Similar content in SOM (2\%) was recorded in all treated soils except for IA.M (2.92\%) and IA.W (3.75\%) soils $(\mathrm{P}<0.05)$. The variation in SOM could be explained by the rapid supply of IA soil by chemical fertilizer. Beside, Dieye et al. (2016), showed that the mineralization of $T$. diversifolia was slow and progressive. The $26 \%$ reduction of TN OA soil compared to $\mathrm{SBC}$, could be explained by high C:N (14) observed in OA soil. Bationo et al. 2008 suggested that rapid decomposition of SOM could result in loss of nutrients through volatilization, leaching; whereas, for slow mineralization of SOM, minerals will have a higher retention time in the soil.

The TN content increased respectively, in IA.M $(1.31 \mathrm{~g} / \mathrm{kg})$, IA.CAL, and IA.W soils where it reached $1.92 \mathrm{~g} / \mathrm{kg}$. These results differed from those obtained by Hafifah et al. (2016), where $T$. diversifolia and cow manure mixture was significantly enriched in OC and TN than the NPK. This could be explained by the high levels of fertilizer used in their study of $1.35 \mathrm{t} / \mathrm{ha}$ NPK, $4.08 \mathrm{t} / \mathrm{ha} T$. diversifolia and $12.93 \mathrm{t} / \mathrm{ha}$ cow manure; the type of crop (cauliflower) and the date of collection of soil samples at the end of the cultivation, which was 30 days. The Control.W soil had the lowest nitrogen content, 1.67 times less than in the SBC. The nitrogen decrease in control soil could be explained by the use of existing nitrogen in the soil for the development of soil microorganisms and even the growth of tomato plants. These results corroborate those of Hafifah et al. (2016), who recorded a 1.83-fold decrease in the total nitrogen content of the control soil compared to the initial soil when the cauliflower was grown. 
Calcium $(\mathrm{Ca})$ concentration and cationic exchange capacity (CEC) were similar in OA and IA soils and were higher than in SBC and control soils $(\mathrm{P}<0.05)$ (Table 3$)$. This increase could be explained by their relatively high clay content, able to bind to organic matter to form the humic argil adsorbent complex. The latter plays an important role in the cation exchange capacity (CEC) for storing many nutrients in the soil and the water retention capacity or Useful Reserve Hubert and Schaub (2011). Also, $\mathrm{Ca}^{2+}$ stabilizes the adsorbing complex by creating a calcium bridge that consolidates the connection between humus and clay. The $\mathrm{pH}$ values of the different soils were similar $(\mathrm{P}<0.05)$ and varied between 6.52 and 7.05. The $\mathrm{pH}$ did not vary during the culture and remained neutral. The soil $\mathrm{pH}$, less than 6.0 tends to be acidic with very high exchangeable aluminum that restricts the growth of most crops (Fairhurst, 2012). Copper $(\mathrm{Cu})$ concentration was reduced by 46.1, 50.7 and $51.9 \%$ respectively, in OA.CAL, OA. M, and OA.W soils compared to $\mathrm{SBC}$ with the highest $\mathrm{Cu}$ concentration (20.53mg. $\left.\mathrm{kg}^{-1}\right)(\mathrm{P}<0.05)$. This decrease could be explained either by the chelation and precipitation of copper by organic matter present in these soils or by the use of copper by the plant for the maturity of fruits (Lopéz-Vargas et al. 2018). All IA soils had a similar $\mathrm{Cu}$ content but showed a reduction of $41 \%$ compared to $\mathrm{SBC}$ soil $(\mathrm{P}<0.05)$. The increase of $\mathrm{Cu}$ in IA.M soil compared to OA.M soil could be due to the supply of these soils by chemical inputs. The iron $(\mathrm{Fe})$ concentration of SBC was identical to that of IA soil and with a decrease of 7.4 and $4.42 \%$ respectively, in OA.W and OA.M soils $(\mathrm{P}<0.05)$. The concentration of $\mathrm{Zn}$ varied according to the nature of sprayed products. The $\mathrm{Zn}$ lowest concentration was recorded in OA soils $(18.8 \mathrm{mg} . \mathrm{kg}$ $\left.{ }^{1}\right)$, representing $48.5 \%$ decrease compared to SBC. This could be due to the complexation of free $\mathrm{Zn}$ with organic matter (Angelova et al. 2013). In control soil, mancozeb further increased the soil $\mathrm{Zn}$ concentration followed by $\mathrm{CAL}$ extract $(\mathrm{P}<0.05)$. The further increase of $\mathrm{Zn}$ to mancozeb plots could be attributed to its $\mathrm{Zn}$ as component chemical composition. In general, there was no accumulation of heavy metals in OA soil. This phenomenon could prevent the long-term onset of soil toxicity.

\subsection{Effects of organic amendment on soil microbial biomass}

Microbial biomass in carbon (MBC) was enriched in $\mathrm{OA}$ and IA soils than $\mathrm{SBC}$ and control soil $(\mathrm{P}<0.05)$ (Table 4). These amended soil also had high clay content. In 2007, Kasel and Bennett reported that an increase in soilclay increases soil micropores hence limiting the development of microorganism predators and thus a protective effect on total microbial biomass. The highest MBC value was recorded from OA.M soil with an increase of $5.8 \%$ and $42.65 \%$, as compared respectively to IA.M soil, and SBC $(\mathrm{P}<0.05)$. High soil microbial biomass often leads to high nutrient availability to crops thus enhancing both the microbial biomass turnover and the degradation of nonmicrobial organic materials (Tu et al. 2006). In the amended soil, MBC vary as a function of the nature of the sprayed products. The MBC content with respect to $\mathrm{SBC}(\mathrm{P}<0.05)$ increased by $20.27 \%$ in IA.W and OA.W soils; $25.16 \%$ in OA.CAL soil; $34.3 \%$ in IA.CAL and IA.M soils; $42.64 \%$ in OA.M soil. The lowest values of microbial biomass in nitrogen $(\mathrm{MBN})$ were recorded in OA.W soil $(0.7 \mathrm{mg} \mathrm{N} . \mathrm{kg}$ $\left.{ }^{1}\right)$ and OA.CAL $\left(0.8 \mathrm{mg} \mathrm{N} \cdot \mathrm{kg}^{-1}\right)$. A five (5) \% increase in MBN was observed in OA.M soil as compared to IA.M soil $(\mathrm{P}<0.05)$.

\subsection{Effects of organic amendment on tomato yield}

The tomato yield was a function of the amendment (Fig 1). The highest yields (107 to 7.33t/ha) were recorded from OA soils, followed by IA soils with yield values ranging from 60.2 to $8 \mathrm{t} / \mathrm{ha}$. Control soils had the lowest yields $(\mathrm{P}<0.05)$. Tomato yield of OA.M plot was 1.8 fold higher that of IA $\mathrm{M}$ plot $(\mathrm{P}<0.05)$. OA CAL plot increased tomato yield by $21 \%$ compared to IA CAL plot $(\mathrm{P}<0.05)$. Ghorbani et al. (2008) found that cattle manure in Iran did not give a good yield of tomato compared to the use of chemical fertilizers. The highest increase of tomato yield obtained with OA.M in this study might be explained by the application of green manures which reduced soil bulk and increased porosity, nutrient content (Adekiya, 2019). Easily available and excessive nitrogen fertilization from inorganic fertilizers delays maturity and may reduce tomato yield. Delayed maturity results in foliage exposed to potential infection for a longer time, increasing the risk of fruit diseases (Ghorbani et al. 2008). The yield increases with the nature of sprayed products; it was higher when the plants were treated with mancozeb fungicide, followed by CAL extract and finally water $(\mathrm{P}<0.05)$.

\subsection{Main Component Analysis between some \\ indicators of soil and different amendments}

The correlation diagram (Fig2) showed that fertility indicators such as $\mathrm{P}, \mathrm{MBN}, \mathrm{TN}$, and SOM contributed to the formation of the $\mathrm{F} 2$ factor and other fertility indicators contributed to the formation of the F1 factor. MBC was strongly correlated with total nitrogen with a correlation coefficient ( $\mathrm{r}=0.801$ to $\mathrm{P}<0.05$ ). Partey et al. (2017), who reported that soil treatment with $T$. diversifolia recorded the greatest effect on the increase of mineral $\mathrm{N}$, soil microbial biomass and $\beta$-glucosidase activities, obtained similar correlation results. The MBN was negatively correlated with $\mathrm{P}(\mathrm{r}=-0.751 \mathrm{P}<0.05)$. There were strong correlations between clay and $\mathrm{Ca}(\mathrm{r}=0.865 \mathrm{P} 0.05)$, clay and cation exchange capacity $(\mathrm{r}=0.845 \mathrm{P}<0.05)$, with a very strong correlation between $\mathrm{Ca}$ and $\mathrm{CEC}(\mathrm{r}=0.932)$. The yield was 
correlated with the adsorbent complex (CEC, Ca, clay). Control soils were negatively correlated to tomato yield and the adsorbing complex. Houot and Chaussod (1995) found a positive correlation between microbial biomass and soil carbon content on wheat-beet rotation conducted with different fertilization types and levels. They also noted decreasing biomass values according to the types of fertilization in the following order: farm fertilizer $>$ mineral fertilization> no fertilization.

\section{FIGURES AND TABLES}

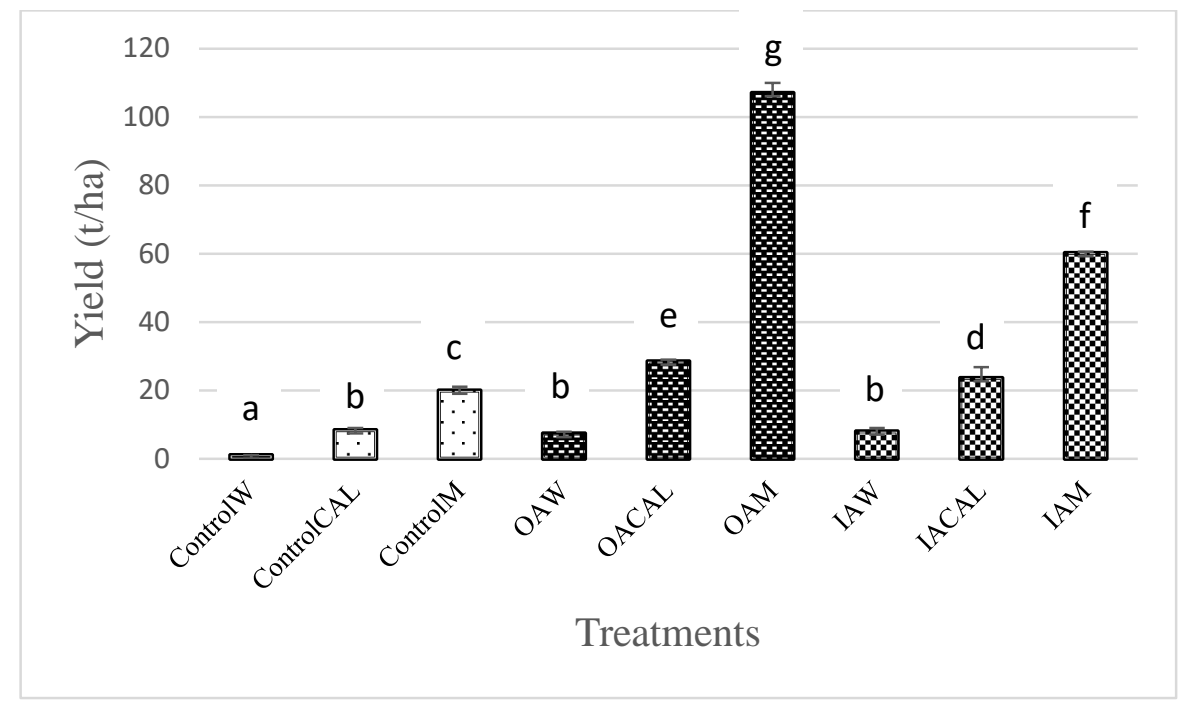

Fig 1: Tomato yield production

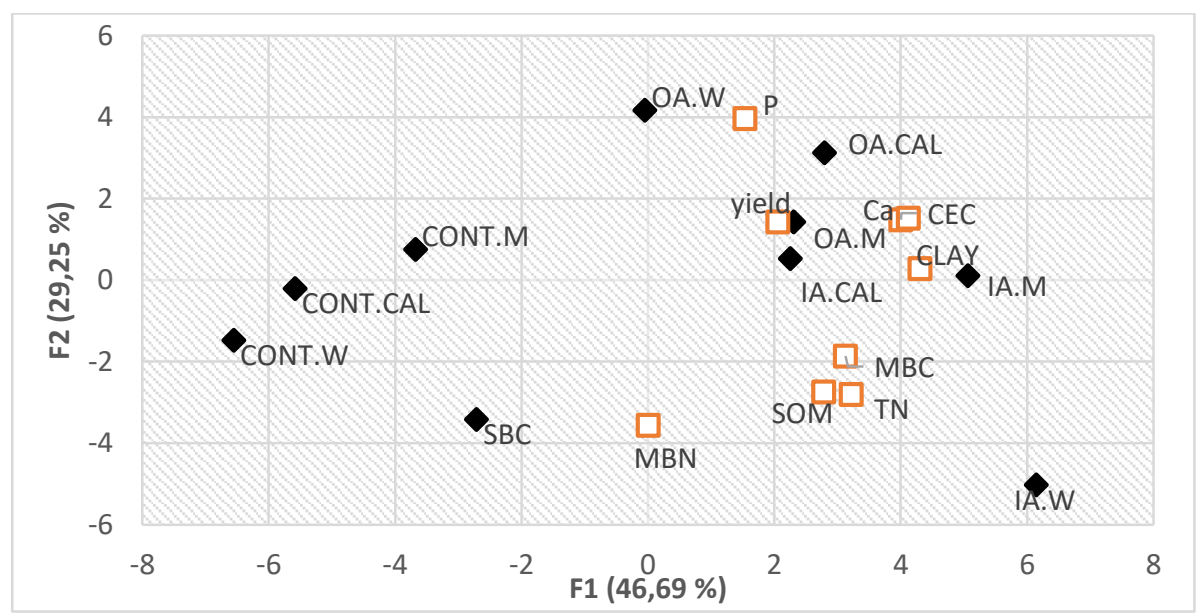

Fig 2: correlation diagram between some soil indicators and different amendments 
Table 1: Granulometry of soil collected at the beginning and end of Lycopersicon esculentum field cultivation

\begin{tabular}{cccc}
\hline Variables & Clay $(\%)$ & Silt $(\%)$ & Salt $(\%)$ \\
\hline SBC & $29.66^{\mathrm{a}}$ & $52^{\mathrm{d}}$ & $18.33^{\mathrm{a}}$ \\
Control.W & $29^{\mathrm{a}}$ & $51.66^{\mathrm{d}}$ & $19.26^{\mathrm{b}}$ \\
Control.CAL & $29^{\mathrm{a}}$ & $51.5^{\mathrm{d}}$ & $19.5^{\mathrm{bc}}$ \\
Control.M & $29.66^{\mathrm{a}}$ & $51.5^{\mathrm{d}}$ & $19.5^{\mathrm{bc}}$ \\
OA.W & $30.33^{\mathrm{ab}}$ & $48^{\mathrm{c}}$ & $21.5^{\mathrm{c}}$ \\
OA.CAL & $33.66^{\mathrm{c}}$ & $46.66^{\mathrm{b}}$ & $20.5^{\mathrm{c}}$ \\
OA.M & $32.33^{\mathrm{abc}}$ & $46.57^{\mathrm{b}}$ & $22.5^{\mathrm{d}}$ \\
IA.W & $33.33^{\mathrm{bc}}$ & $45^{\mathrm{a}}$ & $22^{\mathrm{d}}$ \\
IA.CAL & $31^{\mathrm{ab}}$ & $45.75^{\mathrm{ab}}$ & $23.5^{\mathrm{e}}$ \\
IA.M & $33.33^{\mathrm{bc}}$ & $45^{\mathrm{a}}$ & $21.75^{\mathrm{d}}$
\end{tabular}

Numbers followed by different letter notation in the same column are significantly different based on the Student Newman Keuls (SNK) test at the 5\% level.

Table 2: Macroelements of soil collected at the beginning and end of Lycopersicon esculentum field cultivation

\begin{tabular}{cccccc}
\hline Variables & C:N & OC $(\%)$ & P $\left(\mathbf{m g . k g} \mathbf{~}^{-1}\right)$ & SOM (\%) & TN $\left(\mathbf{g . k g}^{-\mathbf{1}}\right)$ \\
\hline SBC & $11 \pm 1 \mathrm{~b}$ & $1.37 \pm 0.04 \mathrm{bc}$ & $7.96 \pm 1.08 \mathrm{c}$ & $2.36 \pm 0.28 \mathrm{a}$ & $1.23 \pm 0.07 \mathrm{~d}$ \\
Control.W & $16.75 \pm 0.25 \mathrm{e}$ & $1.24 \pm 0.01 \mathrm{ab}$ & $5.95 \pm 0.2 \mathrm{ab}$ & $2.13 \pm 0 \mathrm{a}$ & $0.74 \pm 0 \mathrm{a}$ \\
Control.CAL & $14.75 \pm 0.75 \mathrm{~d}$ & $1.35 \pm 0.1 \mathrm{bc}$ & $9.71 \pm 0.18 \mathrm{~d}$ & $2.3 \pm 0.17 \mathrm{a}$ & $0.9 \pm 0 \mathrm{bc}$ \\
Control.M & $13.75 \pm 0.25 \mathrm{~cd}$ & $1.24 \pm 0.01 \mathrm{ab}$ & $10.53 \pm 0.26 \mathrm{~d}$ & $2.13 \pm 0 \mathrm{a}$ & $0.9 \pm 0 \mathrm{bc}$ \\
OA.W & $14.75 \pm 0.25 \mathrm{~d}$ & $1.25 \pm 0 \mathrm{ab}$ & $4.14 \pm 0.33 \mathrm{a}$ & $2.16 \pm 0.1 \mathrm{a}$ & $0.86 \pm 0 \mathrm{~b}$ \\
OA.CAL & $14.25 \pm 0.75 \mathrm{~cd}$ & $1.39 \pm 0.08 \mathrm{c}$ & $15.54 \pm 0.65 \mathrm{f}$ & $2.39 \pm 0.14 \mathrm{a}$ & $0.96 \pm 0.01 \mathrm{~b}$ \\
OA.M & $12.75 \pm 0.25 \mathrm{c}$ & $1.28 \pm 0.03 \mathrm{abc}$ & $10.76 \pm 0.05 \mathrm{~d}$ & $2.2 \pm 0.04 \mathrm{a}$ & $0.99 \pm 0.01 \mathrm{c}$ \\
IA.W & $11.5 \pm 0.5 \mathrm{c}$ & $2.18 \pm 0.05 \mathrm{e}$ & $6.57 \pm 0.22 \mathrm{~b}$ & $3.75 \pm 0.07 \mathrm{c}$ & $1.92 \pm 0.05 \mathrm{~g}$ \\
IA.CAL & $8 \pm 1 \mathrm{a}$ & $1.18 \pm 0.07 \mathrm{a}$ & $11.79 \pm 0.47 \mathrm{e}$ & $2.03 \pm 0.11 \mathrm{a}$ & $1.44 \pm 0.03 \mathrm{f}$ \\
IA.M & $13.25 \pm 1.25 \mathrm{~cd}$ & $1.69 \pm 0.05 \mathrm{~d}$ & $11.98 \pm 0.23 \mathrm{e}$ & $2.92 \pm 0.16 \mathrm{~b}$ & $1.31 \pm 0.08 \mathrm{e}$
\end{tabular}

Numbers followed by different letter notation in the same row are significantly different based on the Student Newman Keuls (SNK) test at the 5\% level. 
International Journal of Environment, Agriculture and Biotechnology, 5(2)

Mar-Apr, 2020 / Available: https://ijeab.com/

Table 3: Mineral elements of soil collected at the beginning and end of Lycopersicon esculentum field cultivation

\begin{tabular}{|c|c|c|c|c|c|c|c|c|c|c|}
\hline Variables & SBC & Control.W & Control.CAL & Control.M & OA.W & OA.CAL & OA.M & IA.W & IA.CAL & IA.M \\
\hline $\mathrm{Ca}^{++}\left(\mathrm{cmol}^{(+)} \cdot \mathrm{kg}^{-1}\right)$ & $12.18 \pm 0.52^{\mathrm{b}}$ & $11.41 \pm 0.22^{\mathrm{ab}}$ & $10.64 \pm 0.34^{\mathrm{a}}$ & $12.47 \pm 1.49^{\mathrm{b}}$ & $15.88 \pm 0.12^{\mathrm{c}}$ & $16.07 \pm 0.26^{\mathrm{c}}$ & $15.63 \pm 0.1^{\mathrm{c}}$ & $15.77 \pm 0.34^{\mathrm{c}}$ & $15.8 \pm 0.01^{\mathrm{c}}$ & $15.81 \pm 0^{\mathrm{c}}$ \\
\hline $\operatorname{CEC}\left(\mathrm{cmol}^{(+)} \cdot \mathrm{kg}^{-1}\right)$ & $30.81 \pm 1.53^{\mathrm{a}}$ & $33.61 \pm 1.13^{\mathrm{b}}$ & $34.3 \pm 0.02^{\mathrm{b}}$ & $38.62 \pm 3.37^{\mathrm{c}}$ & $43.5 \pm 0.24^{\mathrm{d}}$ & $45.68 \pm 0.89^{\mathrm{d}}$ & $44.1 \pm 0.22^{\mathrm{d}}$ & $46.7 \pm 0.76^{\mathrm{d}}$ & $46.52 \pm 0^{\mathrm{d}}$ & $46.03 \pm 0.63^{d}$ \\
\hline pH & $6.8 \pm 0.62^{\mathrm{a}}$ & $6.55 \pm 0.05^{\mathrm{a}}$ & $7.05 \pm 0.05^{\mathrm{a}}$ & $6.75 \pm 0.25^{\mathrm{a}}$ & $6.52 \pm 0.02^{\mathrm{a}}$ & $6.62 \pm 0.07^{\mathrm{a}}$ & $6.57 \pm 0.02^{\mathrm{a}}$ & $6.67 \pm 0.27^{\mathrm{a}}$ & $6.8 \pm 0.15^{\mathrm{a}}$ & $6.8 \pm 0.1^{\mathrm{a}}$ \\
\hline $\mathrm{Cu}\left(\mathrm{mg} \cdot \mathrm{kg}^{-1}\right)$ & $20.53 \pm 0.38^{d}$ & $11.64 \pm 0.04^{\mathrm{c}}$ & $11.67 \pm 0.17^{\mathrm{c}}$ & $12.03 \pm 0.1^{\mathrm{c}}$ & $9.88 \pm 0.18^{\mathrm{a}}$ & $11.06 \pm 0.09^{\mathrm{b}}$ & $10.12 \pm 0.18^{\mathrm{a}}$ & $12.04 \pm 0.36^{\mathrm{c}}$ & $12.04 \pm 0.09^{\mathrm{c}}$ & $12.08 \pm 0.2^{\mathrm{c}}$ \\
\hline $\mathrm{Fe}\left(\mathrm{mg} \cdot \mathrm{kg}^{-1}\right)$ & $84.96 \pm 0.78^{\mathrm{d}}$ & $83.8 \pm 0.2^{\mathrm{d}}$ & $77 \pm 0.1^{\mathrm{a}}$ & $80.72 \pm 0.22^{\mathrm{c}}$ & $78.67 \pm 1.27^{\mathrm{b}}$ & $84.64 \pm 0.74^{\mathrm{d}}$ & $81.2 \pm 1.7^{\mathrm{c}}$ & $83.08 \pm 0.17^{\mathrm{d}}$ & $83.59 \pm 0.63^{\mathrm{d}}$ & $83.7 \pm 0.29^{d}$ \\
\hline Zn (mg.kg $\left.{ }^{-1}\right)$ & $28.98 \pm 0.69^{\mathrm{e}}$ & $19.89 \pm 0^{\mathrm{b}}$ & $21.35 \pm 0.29^{c}$ & $22.94 \pm 0.5^{\mathrm{d}}$ & $17.79 \pm 0.14^{\mathrm{a}}$ & $19.35 \pm 0.05^{\mathrm{b}}$ & $19.36 \pm 0.56^{b}$ & $21.95 \pm 0.07^{\mathrm{c}}$ & $23.63 \pm 0.01^{\mathrm{d}}$ & $22.9 \pm 0.36^{\mathrm{d}}$ \\
\hline
\end{tabular}

Numbers followed by different letter notation in the same row are significantly different based on the Student Newman Keuls (SNK) test at the 5\% level

Table 4: microflora of soil collected at the beginning and end of Lycopersicon esculentum field cultivation

\begin{tabular}{lll}
\hline \multicolumn{1}{c}{ Variables } & MBC $\left(\mathbf{m g . k g} \mathbf{k g}^{-\mathbf{1}}\right)$ & MBN $\left(\mathbf{m g . k g}^{-\mathbf{1}}\right)$ \\
\hline SBC & $440.36 \pm 0.93^{\mathrm{a}}$ & $0.9 \pm 0^{\mathrm{e}}$ \\
Control.W & $455.37 \pm 0.42^{\mathrm{a}}$ & $0.89 \pm 0.01^{\mathrm{e}}$ \\
Control.CAL & $478.21 \pm 5.95^{\mathrm{b}}$ & $0.82 \pm 0^{\mathrm{c}}$ \\
Control.M & $462.88 \pm 8.17^{\mathrm{a}}$ & $0.85 \pm 0^{\mathrm{d}}$ \\
OA.W & $534.24 \pm 5.64^{\mathrm{c}}$ & $0.7 \pm 0^{\mathrm{a}}$ \\
OA.CAL & $551.17 \pm 3.75^{\mathrm{d}}$ & $0.8 \pm 0.01^{\mathrm{b}}$ \\
OA.M & $628.16 \pm 5.63^{\mathrm{f}}$ & $0.89 \pm 0.02^{\mathrm{e}}$ \\
IA.W & $524.85 \pm 3.76^{\mathrm{c}}$ & $0.9 \pm 0.01^{\mathrm{e}}$ \\
IA.CAL & $586.83 \pm 3.1^{\mathrm{e}}$ & $0.85 \pm 0.02^{\mathrm{d}}$ \\
IA.M & $596.31 \pm 13.08^{\mathrm{e}}$ & $0.85 \pm 0^{\mathrm{d}}$
\end{tabular}

Numbers followed by different letter notation in the same row are significantly different based on the Student Newman Keuls (SNK) test at the 5\% level 


\section{CONCLUSION}

From this study, it established that organic amendment combined with treatment of tomato plants with extract of Callistemon Citrinus improved soil quality by increasing available phosphorus, calcium, cation exchange capacity, and by reducing soil heavy metal accumulation. Therefore, it constitutes an environment eco-friendly integrated strategy for soil fertilization. Also, the combination of organic amendment and chemical pesticide (mancozeb) spraying improved MBC concentration and tomato yield. This combination could be a solution in crop production management. Whereas, low concentration of organic amendment did not increase SOM content and thus there need for further investigation to establish an optimum concentration of organic inputs.

\section{ACKNOWLEDGMENTS}

Development and Agricultural Research Institute (IRAD) Yaoundé for field activities, and the determination of microorganisms of microflora;

Research Unity of Soil Analysis and Environmental Chemistry (RUSAEC) of the University of Dschang for physicochemical analysis and microbial biomass analysis.

\section{REFERENCES}

[1] Adegunloye, D.V., Adetuyi, F.C., Akinyosoye, F.A. and Doyeni, M.O. (2007) Microbial analysis of compost using cow dung as a booster. Pakistan Journal of Nutrition, 6, 506510.

[2] Adekiya, A.O. (2018). Legume mulch materials and poultry manure affect soil properties, and growth and fruit yield of tomato. Agriculturae Conspectus Scientificus, 83 (2), 161167

[3] Adekiya. A. O. (2019). Green manures and poultry feather effects on soil characteristics, growth, yield and mineral contents of tomato. Scientia Horticulturae, 257, 108721.

[4] Aghofack-Nguemezi, J. and Schwab, W. (2014). Differential accumulation of flavonoids by tomato (Solanum Lycopersicum) fruits tissues during maturation and ripening. Journal of Applied Bioscience, 84, 7674-7681.

[5] Aguyoh, J.N., Audi, W., Saidi, M. and Gao-Qiong, L (2010). Growth, yield and quality response of watermelon (Citrullus lanatus CV. Crimson Sweet) subjected to different levels of tithonia manure. International Journal of Science and Nature, $1(1), 7-11$.

[6] Angelova, V.R., Akova, V.I., Artinova, N.S. and Ivanov, K.I. (2013) .The effect of organic amendment on soil chemical characteristics. Bulgarian Journal of Agricultural Science, 19, 958-971.

[7] Babajide, P.A., Olabode, O.S., Akanbi, W.B., Olatunji, O.O. and Ewetola, E.A. (2008). Influence of composted Tithonia mineral fertilizer on soil physic properties and performance of Tomato (Lycopersicon lycopersicum). Research Journal of Agronomy, 2, 101-106. ISSN 2071-7024

[8] Bationo, A., Kihara, J., Vanlauwe, B., Waswa, B. and Kimetu, J. (2008): Soil organic carbon dynamics, functions and management in West African agro-ecosystems. Agricultural Systems, 94, 13-25.

[9] Bray, R.H. and Kurtz, L.T. (1945). Determination of total, organic, and available forms of phosphorus in soils. Soil Science, 59, 39-45.

[10] Chaussod, R., Houot, S., Guiraud, G. and Hetier, L.M. "size and turnover of the microbial biomass in agricultural soils: laboratory and field measurements" in D.S. JENKINSON and KA SMITH editions, 1988, 312-326.

[11] Crespo, G., Ruiz, T.E. and Álvarez, J. (2011). Effect of green manure from Tithonia ( $T$. diversifolia) on the establishment and production of forage of P. purpureum cv. Cuba CT-169 and on some soil properties. Cuban Journal of Agriculture Science, 45, 79-82.

[12] Dakole, D.C., Nguefack, J., Dongmo, L.B.J., Galani, Y.J.H., Azah, U.R., Somda, I and Amvam Z.P.H. (2016). Antifungal potential of essential oils, aqueous and ethanol extracts of thirteen plants against Fusarium oxysporum f. sp Lycopersici and phytophtora infestans (Mont.) de Bary as major tomato pathogens in Cameroon. International journal of current Research, 19(2), 128-145.

[13] Diacono, M. and Montemurro, F. (2010). Long-term effects of organic amendments on soil fertility-A review. Agronomy for Sustainable. Development, 30, 401-422.

[14] Dieye, T., Assigbetse, K., Diedhiou, I., Sembene, M., Dieng, A.L., Gueye, M. and Masse, D. (2016). The effect of Jetropha.curcas L. leaf litter decomposition on soil carbon and nitrogen status and bacterial community structure (Senegal). Journal of Soil Sciences and Environment, 7, 32-44.

[15] Fairhurst, T. Africa Soil Health Consortium. Handbook for integrated soil fertility management edition, (2012).

[16] FAOSTAT. (2019). Food and Agriculture Organization of the United Nations. https:// faostat3. Fao.org/download/Q/QC/E. Consulted on 10-9-2019.

[17] Galani, Y.J.H., Nguefack, J., Dakole, D.C., Fotio, D., Petchayo, T.S., Fouelefack F.R. and Amvam, Z.P.H. (2013). Antifungal potential and phytochemical analysis of extracts from seven Cameroonian plants against late blight pathogen Phytophthora infestans. International Journal of Current Microbiology and Applied Sciences, 2 (5), 140-154.

[18] Ghorbani, R., Koocheki, A., Jahan, M. and Asadi, G.A. (2008). Impact of organic amendments and compost extracts on tomato production and storability in agroecological systems. Agronomy for. Sustainable Development, 28, 307311. DOI: 10.1051/agro:2008003

[19] Goufo, P., Fontem, D.A. and Ngnokam, D (2010). Evaluation of plant extracts for tomato late blight control in Cameroon. N Z Journal of Crop and Horticulturae Science, 38 (3), 171176.

[20] Hafifah, S., Maghfoer, M.D. and Prasetya, B. (2016). The potential of Tithonia diversifolia green manure for improving soil quality for cauliflower (Brassica oleracea var. Brotrytis 
L.). Journal of Degraded and Mining Land Management, 3 (2), 499-506.

[21] Houot, S. and Chaussod, R. (1995). Impact of Agricultural Practices on the size and activity of the microbial biomass in à long-term field experiment. Biology and Fertility Soil, 19,309-316.

[22] Hubert, G. and Schaub, C. (2011). Soil fertilization. The importance of organic matter. Chamber of Agriculture. BasRhin: Environment-Innovation Department 46

[23] Jama, B., Buresh, C.A., Niang, R.J., Gachengo, A., Nziguheba, C. and Amadalo, B. (2000). Tithonia diversifolia as green manure for soil fertility improvement in western Kenya: A review. Agroforestry Systems, 49, 201-221.

[24] Kagale, S., Marimuthu, T., Thayumanavan, B., Nandakumar, R. and Samiyappan, R. (2004). Antimicrobial activity and induction of systemic resistance in rice by leaf extract of Datura metel against Rhizoctonia solani and Xoo. Physiology Molecular Plant Pathology, 65, 91-100.

[25] Kasel, S. and Bennett, L.T. (2007). Land-use history, forest conversion, and soil organic carbon in pine plantations and native forests of south-eastern Australia. Geoderma, 137, 401-413.

[26] Komakech, A.J., Banadda, N.E., Gebresenbet, G. and Vinnerås, B. (2014). Maps of animal urban agriculture in Kampala City. Agronomy for. Sustainable. Development, 34, 493-500.

[27] Konje, C.N., Abdulai, A.N., Tange, D.A., Nsobinenyui, D., Tarla, D.N. and Tita, M.A. (2019). Identification and management of pests and diseases of garden crops in Santa Cameroon. Journal of Agriculture and Ecology Research International, 18, 1-9.

[28] Lopez-Vargas, E.R.., Ortega-Ortiz, H., Cadenas-Pliego, G., Romenus, K.A., Fuente, M.C., Benavides-Mendoza, A. and Juarez-Maldonado, A. (2018). Foliar application of copper nanoparticles increases the fruit quality and content of bioactive compounds in tomatoes. Applied Science, 8, 10201.

[29] Mekam, P.N., Martini, S., Nguefack, J., Tagliazucchi, D., Mangoumou, G.N. and Stefani, E. (2019). The activity of extracts from three tropical plants towards fungi pathogenic to tomato (Solanum lycopersicum). Phytopathologia Mediterranea, 58(3), 57-586.

[30] Monkiedje, A., Spiteller, M., Fotio, D. and Sukul, P. (2006). The effect of land use on soil health indicators in peri-urban agriculture in the humid forest zone of Southern Cameroon. Journal of Environment and Quality, 63, 973-975.

[31] Ndonkeu, M.G., Nguefack, J., Galani, Y.J.H., Petchayo, T.S. and Amvam, Z.P.H. (2013). Antifungal potential of extracts from three plants against two major pathogens of celery (Apium graveolens L.) in Cameroon. International Journal of Current Science, 5, 4091-4096.

[32] Nguefack, J., Wulff, E.G., Dongmo, L.J.B., Fouelefack, F.R., Mbo, J. and Torp, J. (2013). Effect of plant extracts and essential oil on the control of brown spot disease, tillering, number of panicles and yield increase in rice. European Journal of Plant Pathology, 137, 871-882.

[33] Olanya, O.M. and Larkin, R.P. (2006). Efficacy of essential oils and biopesticides on Phytophthora infestans suppression in laboratory and growth chamber studies. Biocontrol Science and Technology, 16(9), 901-917.

[34] Partey, S.T., Zougmore, R.B., Thevathasan, N.V. and Preziosi, R.F. (2017). N availability, soil microbial biomass and $\beta$-glucosidase activity as influenced by the decomposition of nine plant residues during soil fertility improvement in Ghana. Pedosphere, ISSN 1002-0160/CN 32-1315/P doi:10.1016/S1002-0160(17)60433-8.

[35] Rivaie, A.A., Loganathan, P., Graham, J.D., Tillman, R.W and Payn, T.W. (2008). Effect of phosphate rock and triple superphosphate on soil phosphorus fractions and their plantavailability and downwardmovement in two volcanic as soils under Pinus Radiataplantations in New Zealand. Nutrient Cycling in Agroecosystems, 82, 75-88.

[36] Tu, C., Jean, B., Ristaino, J.B. and Hu, S. (2006). Soil microbial biomass and activity in organic tomato farming systems: effects of organic inputs and straw mulching. Soil Biology and Biochemistry, 38, 247-255.

[37] Walkley, A. and Black, C.A. (1934). An examination of the Degtjareff method for determining soil organic matter and a proposed modification of the chromic acid titration method. Soil Science, 37, 29-38.

[38] Wu, J., Joergenson, R.G., Pommerening, B., Chaussod, R. and Brookes, P.C. (1990). Measurement of soil microbial biomass Carbon by fumigation-extraction - An automated procedure. Soil Biology and Biochemistry, 22, 1167-1169.

[39] Zinkakuba, L.V., Mwanyikag, G., Ntwenga, J.E. and James, A. (2019). Pesticide regulations and their malpractice implications on food and environment safety. Food Science and Technology, 5, 1601544

[40] Zwolak, A., Sarzyńska, E.S. and Stawrczyk, K. (2019).Sources of soil pollution by heavy metals and their accumulation in vegetables: a review. Water Air and Soil Pollution, 230(164), 1-9 